\title{
PENGARUH KEPRIBADIAN, KECERDASAN EMOSIONAL DAN KECERDASAN SPIRITUAL TERHADAP KINERJA KARYAWAN
}

\author{
Nina Octavia \\ Bandar Lampung, Lampung \\ Keumala Hayati \\ Mirwan Karim \\ Jurusan Manajemen Fakultas Ekonomi dan bisnis Universitas Lampung \\ Keumala.hayati@feb.unila.ac.id
}

\begin{abstract}
ABSTRAK
Penelitian ini bertujuan untuk mengetahui pengaruh kepribadian, kecerdasan emosional dan kecerdasan spiritual terhadap kinerja karyawan. Sampel penelitian adalah 208 karyawan yang bekerja pada perusahaan retail di Lampung. Pengumpulan data dilakukan dengan menggunakan kuesioner, sedangkan alat analisis data menggunakan SPSS. Hasil penelitian menunjukkan bahwa kepribadian, kecerdasan emosional dan kecerdasan spiritual berpengaruh positif terhadap kinerja karyawan. Kecerdasan spiritual memiliki pengaruh paling besar dibandingkan kepribadian dan kecerdasan emosional. Saran penelitian ini adalah untuk meningkatkan kepercayaan diri karyawan, senantiasa berfikir dengan baik untuk merespons setiap situasi, memiliki tenggang rasa agar dapat memahami emosi teman kerja dengan lebih baik, serta memperhatikan kemampuan karyawan mengatur rencana kerja sendiri untuk memaksimalkan pekerjaan serta selesai tepat waktu.
\end{abstract}

Kata kunci: Kepribadian, Kecerdasan Emosional, Kecerdasan Spiritual Kinerja Karyawan

\begin{abstract}
This study aims to explore the effect of personality, emotional intelligence, and spiritual intelligence on employee performance. The study sample was 208 employees who worked at retail companies in Lampung. Data collection conducted using a questionnaire, and the data analysis tool uses SPSS. The results showed that personality, spiritual intelligence, and emotional intelligence had a positive effect on employee performance. Spiritual intelligence has the most influence compared to personality and emotional intelligence. The suggestion of this research is to increase employee confidence, be able to think well in response to every situation, have a sense of tolerance to better understand coworkers 'emotions, and pay attention to employees' ability to manage their work plans so that maximize their work and completed on time.
\end{abstract}

Keywords: Personality, Emotional Intelligence, Spiritual Intelligence, Employee Performance 


\section{PENDAHULUAN}

Sumber daya manusia yang berkualitas dan terampil adalah salah satu modal yang harus dimiliki perusahaan untuk mencapai tujuan. Diantara aspek sumber daya manusia yang perlu diperhatikan adalah keterampilan dan kemampuan karyawan, kapabilitas manajemen serta keterkaitannya dengan strategi sumber daya manusia untuk mencapai kinerja yang tinggi (Limawandoyo, 2013). Dalam upaya mewujudkan kinerja yang tinggi, perlu dilandaskan pada salah satu diantaranya yaitu pendekatan psikologis dan organisasi (Mangkunegara, 2014: 4). Pendekatan ini adalah pendekatan terhadap kepribadian dan kecerdasan dari aspek manusia di dalam perusahaan.

Pendekatan kepribadian adalah diantara salah satu faktor psikologi yang dapat mempengaruhi kinerja. Kepribadian memberikan panduan umum yang mengarahkan kepada kinerja yang efektif (Indarti et al., 2014). Salah satu model pengukuran yang digunakan sebagai bagian dari dimensi kepribadian adalah The big five Inventory”. Konsep ini dikemukakan oleh John dan Kentle pada tahun 1991 (Rammstedt dan John, 2007). Umumnya hasil penelitian menyimpulkan bahwa pendekatan trait terhadap kepribadian dapat dilihat dari lima dimensi. Kelima dimensi yang disebut dengan Big Five tersebut adalah neuroticism, extraversion, openness to experience, agreeableness dan conscientiousness (Friedman dan Schustack, 2016: 112).

Beberapa hasil penelitian menunjukkan terdapat kesenjangan pengaruh kepribadian terhadap kinerja sebagain menyatakan berpengaruh sedangkan sebagian lainnya menyatakan tidak. Yang dan Hwang (2014) menyatakan bahwa semua trait dalam kepribadian berpengaruh positif secara signifikan terhadap kinerja. Berbeda dengan penelitian Muhaimin et al. (2011). Penelitia tersebut menunjukkan karakteristik kepribadian tidak berpengaruh positif signifikan terhadap kinerja karyawan. Hasil penelitian Wicaksono dan Surjanti (2016) menemukan hanya dua indikator yang berpengaruh signifikan terhadap kinerja yaitu, Opennes to Experience dan Conscientiousness.

Selain kepribadian, faktor kecerdasan juga salah satu faktor psikologi yang dapat mempengaruhi kinerja karyawan. Kecerdasan spiritual di tempat kerja adalah suatu pengenalan diri karyawan bahwa ada kehidupan batiniah yang mendukung dan memelihara diri. Kehidupan batiniah tersebut berada dalam pekerjaan yang bermakna yang berada dalam konteks sebuah komunitas (Ashmos dan Duchon, 2000). Spiritualitas didalam pekerjaan dapat memberikan dampak positif kepada karyawan dan perusahaan (Nurtjahjanti, 2010).

Kecerdasan emosional dan kecerdasan spiritual memberikan sumbangan yang besar terhadap kinerja yaitu $80 \%$, sedangkan sisanya $20 \%$ disumbang dari kecerdasan intelektual (IQ) (Goleman, 2015:78). Robbins dan Judge (2013: 335) juga menyatakan bahwa kecerdasan emosional menjadi karakteristik kinerja yang tinggi, bukan kecerdasan intelektual. Diantara model untuk mengukur kecerdasan emosional yang umum digunakan dalam dimensi kecerdasan emosional adalah "Wong and Law Emotional Intellience Scale (WLEIS)" (Wong dan Law, 2004). Dimensi kecerdasan emosional terdiri dari empat dimensi yaitu, self emotional appraisal (SEA), use of emotion (UOE), other's emotional appraisal (OEA) dan regulation of emotion (ROE).

Hasil penelitian terdahulu juga menunjukkan bahwa kecerdasan emosional berdampak terhadap kinerja (Shih dan Susanto, 2010). Semua dimensi di dalam WLEIS memberikan hasil yang signifikan (Sulaiman dan Noor, 2015). Diantara keempat dimensi tersebut hanya dimensi Other's Emotional Appraisal (OEA) yang memiliki hubungan siginifikan dan reliabilitas yang tinggi (Sulaiman dan Noor, 2015; Ramadhani (2016).

Hasil penelitian oleh Indriyani dan Utami (2018) menunjukkan bahwa baik variabel kecerdasan spiritual maupun variabel kecerdasan emosional berpengaruh signifikan 
terhadap kinerja karyawan. Dengan demikin kinerja karyawan dapat didefinisikan sebagai hasil kerja baik secara kualitas maupun kuantitas yang merupakan capaian seorang karyawan. Kinerja tersebut dicapai dalam melaksanakan tugas sesuai dengan tanggung jawab yang diberikan (Mangkunegara, 2014: 10).

Penelitian ini dilakukan pada perusahaan retail di Bandar Lampung. Perusahaan ini merupakan perusahaan swasta yang bergerak dalam bidang distribusi barang yang berhasil meraih beberapa prestasi. Prestasi tersebut berupa perusahaan waralaba unggul serta perusahaan waralaba kategori utama versi Kementrian Perdagangan pada tahun 2016. Penghargaan tersebut membuktikan bahwa perusahaan retail ini memiliki pendekatan sistematis terhadap kesehatan, keselamatan, keamanan dan manajemen lingkungan untuk mencapai perbaikan kinerja yang berkelanjutan. Penelitian ini dilakukan pada perusahaan retail di Bandar Lapung untuk menggali kepribadian, kecerdasan emosional serta kecerdasan spiritual karaywannya. Ketiga faktor tersebut merupakan pendekatan psikologis yang dimiliki oleh seorang karyawan.

\section{KAJIAN LITERATUR Kepribadian}

Kepribadian adalah suatu sifat atau trait. Trait adalah dimensi perbedaan individu berkaitan dengan kecenderungan yang menunjukkan pola konsisten dalam pikiran, perasaan, dan tindakan (McCrae dan Costa dalam Rammstedt dan John, 2007). Kepribadian adalah serangkaian ciri yang relatif tetap dan sebagian besarnya dibentuk dari faktor keturunan, lingkungan, sosial serta kebudayaan (Hasibuan, 2014).

\section{Dimensi Kepribadian}

Trait memiliki lima 5 dimensi dalam kepribadian manusia. Berdasarkan teori kepribadian yang dikembangkan oleh McCrae dan Costa kelima dimensi tersesbut dikenal dengan istilah Five-Factor Model (FFM) (Rammsted dan John (2007). Kelima dimensi tersebut dapat diljabarkan sebagai berikut (McCrae dan Costa (1997) dalam Muhaimin, et al., 2011):

1. Neuroticism adalah besarnya sensasi negatif seseorang. Sifat kepribadian ini menunjukan adanya kecenderungan untuk mengekspresikan emosi yang buruk. Karakteristik khas dari orang yang berkepribadian ini adalah takut, gugup, dan suka berlebihan.

2. Extraversion merupakan sifat kepribadian yang berhubungan dengan emosi dan perasaan senang terhadap dirinya sendiri dan lingkungan di sekitarnya, serta tingkat kenyamanan seseorang ketika bekerja dengan orang lain.

3. Opennes to Experience adalah sifat yang terbuka terhadap hal-hal baru. Tipe yang terbuka terhadap pengalaman yaitu tingkat kedalaman minat terhadap pengetahuan. Ciri atau karakteristik khusus tipe kepribadian ini adalah penuh daya imajinasi, cerdas dan berwawasan luas.

4. Agreeableness adalah sifat yang mudah akur atau mudah bersepakat. Sifat keramahan ini adalah tingkat ketaatan norma individu. Karakteristik khususnya kepribadian ini adalah ramah, toleran dan bersahabat.

5. Conscientiousness dalah sifat berhati-hati atau kesadaran hati nurani. Kepribadian ini adalah kerpibadian yang senantiasa berkonsentrasi untuk mencapai tujuan. Karakteristik khusus orang yang memiliki kepribadian ini adalah berprestasi, disiplin dan taat serta berorientasi. 


\section{Kecerdasan Spiritual}

Kecerdasan spiritual adalah satu set kapasitas mental yang berkontribusi terhadap kesadaran, integrasi, dan aplikasi adaptif aspek nonmaterial. Aspek nonmateri ini disadari di area transenden yang mengarah kepada hasil seperti eksistensial yang mendalam, peningkatan makna, pengakuan dari transendensi-diri, serta penguasaan spiritual (King, 2008), Zohar dan Marshal (2013: 7) menyatkan kecerdasan spiritual sebagai moral, kemampuan untuk menyesuaikan aturan yang kaku yang dibarengi dengan pemahaman dan cinta. Selain itu juga serta kemampuan yang setara untuk melihat kapan cinta dan pemahaman sampai pada batasannya, juga memungkinkan kita bergulat dengan hal ihwal baik dan jahat, membayangkan yang belum terjadi serta mengangkat kita dari kerendahan.

Terdapat empat komponen kecerdasan spiritual (King, 2008). Masing-masing komponen mewakili pengukuran kecerdasan spiritual secara menyeluruh sebagai berikut:

1. Critical Existential Thinking (CET). Komponen ini adalah kecerdasan spiritual yang melibatkan kemampuan untuk merenungkan makna, tujuan, dan isu-isu eksistensial atau metafisik lainnya secara kritis (misalnya realitas, ruang, waktu, alam, semesta dan kematian). Eksistensi dari berpikir kritis dapat diterapkan pada setiap masalah kehidupan. Setiap objek atau kejadian pada dasarnya dapat dilihat dalam kaitannya dengan eksistensi seseorang.

2. Personal Meaning Production (PMP). Komponen kecerdasan kedua ini adalah kemampuan membangun makna pribadi dan tujuan dalam setiap pengalaman baik fisik maupun mental, termasuk juga didalamnya kemampuan untuk membuat dan menguasai tujuan hidup. Frankl Dalam Zohar \& Marshall (2013) menyatakan bahwa pencarian akan makna merupakan motivasi paling penting dalam kehidupan.

3. Transcendental Awareness (TA). Komponen ketiga adalah kecerdasan yang melibatkan kemampuan untuk melihat dimensi baik dalam transenden diri, orang lain, atau dunia fisik (misalnya nonmaterial) dalam keadaan normal maupun dalam keadaan membangun area kesadaran. Wolman (2001) dalam King (2008) memaparkan bahwa kesadaran transendental adalah kemampuan untuk merasakan dimensi spiritualitas dalam kehidupan. Kesadaran inimencerminkan apa yang digambarkan sebelumnya sebagai merasakan kehadiran yang nyata, yang lebih tersebar dan umum dari indera khusus kita.

4. Conscious State Expansion (CSE). Komponen kecerdasan terakhir adalah kemampuan untuk memasukan area kesadaran spiritual (misalnya kesadaran murni dan kesatuan) ke dalam kebijakannya sendiri. Kesadaran diri (self consciousness atau sering disebut juga dengan self awareness) adalah pembeda utama pada orang yang memiliki spiritualisme tinggi dengan yang tidak. Orang yang memiliki kesadaran yang tinggi akan selalu berpikir berkali-kali ketika merespons suatu situasi, membutuhkan sejenak waktu untuk memahami apa yang tersembunyi maupun yang nyata sebelum menunjukan respons awal.

\section{Kecerdasan Emosional}

Kecerdasan emosional adalah kemampuan seseorang untuk menangani emosi di dalam dirinya (Law, et al., 2004). Salovey dan Mayer (1990) dalam Shih dan Susanto (2010) menyatakan kecerdasan emosional adalah bagian dari kecerdasan sosial. Kecerdasan ini melibatkan kemampuan individu untuk memonitor perasaan sosial dan emosi yang ada pada orang lain, memilah-milah semuanya, serta menggunakan informasi tersebut untuk membimbing proses berpikir mereka. Law, et al. (2004) mengukur kecerdasan emosional kepada empat dimensi berikut: 
1. Self emotion appraisal (SEA) adalah kemampuan seseorang mengenali suasana hati, baik di dalam diri sendiri maupun bagaimana mengekspresikan emosinya. Dimensi ini menilai bagaimana individu memahami perasaan dirinya sendiri serta bagaimana kemampuannya menilai perasaan diri sendiri.

2. Others emotion appraisal (OEA) adalah kemampuan individu merasakan dan memahami emosi orang-orang disekitarya. Individu yang memiliki kemampuan ini yang tinggi akan jauh lebih sensitive terhadap perasaan dan emosi orang lain.

3. Use of emotion (UOE) adalah kemampuan individu menggunakan emosinya. Kemampuan ini dapat mengarahkan individu ke arah kegiatan yang lebih konstruktif, serta kinerja yang dapat lebih terkendali.

4. Regulation of emotion (ROE) adalah kemampuan mengatur emosi diri sendiri, sehingga dapat dengan dengan cepat memulihkan diri dari tekanan psikologis.

\section{Kinerja Karyawan}

Kinerja adalah perilaku dan tindakan yang berhubungan dengan tujuan perusahaan (Koopmans, et al., 2014: 331). Kinerja ialah hasil kerja secara kualitas dan kuantitas yang dicapai seorang karyawan dalam melaksanakan tugasnya sesuai dengan tanggung jawab yang diberikan kepadanya (Mangkunegara, 2014: 9). Terdapat tiga dimensi untuk mengukur kinerja karyawan secara individu, yaitu (Koopmans, et al, 2014):

1. Kinerja tugas

Kinjer tugas mengacu pada kemampuan dan keterampilan karyawan dalam melaksanakan tugas pokok. Perilaku yang menggambarkan kinerja tugas adalah kualitas dan kuantitas kerja, pengetahuan terhadap pekerjaan serta keterampilan kerja.

2. Kinerja kontekstual

Kinerja kontekstual mengacu pada perilaku yang mendukung lingkungan perusahaan, lingkungan psikologis serta lingkungan sosial tempat bekerja. Perilaku yang menggambarkan kinerja kontekstual seperti mengerjakan tugas tambahan, memfasilitasi rekan kerja, serta kemampuan bekerja sama dan berkomunikasi.

3. Perilaku kerja yang tidak produktif

Perilaku kerja yang tidak produktif adalah perilaku yang mengganggu atau membahayakan kinerja perusahaan. Contoh perilaku ini adalah absensi, menyalahgunakan jabatan, dan mencuri di tempat kerja.

\section{Kerangka Pemikiran}

Kerangka peneilitian ini dapat dilihat pada Gambar 1. Gambar 1 menunjukkan kerangka pemikiran guna menggambarkan hubungan antara variabel independen dan variabel dependen. Berikut adalah rerangka pemikiran dari penelitian ini : 


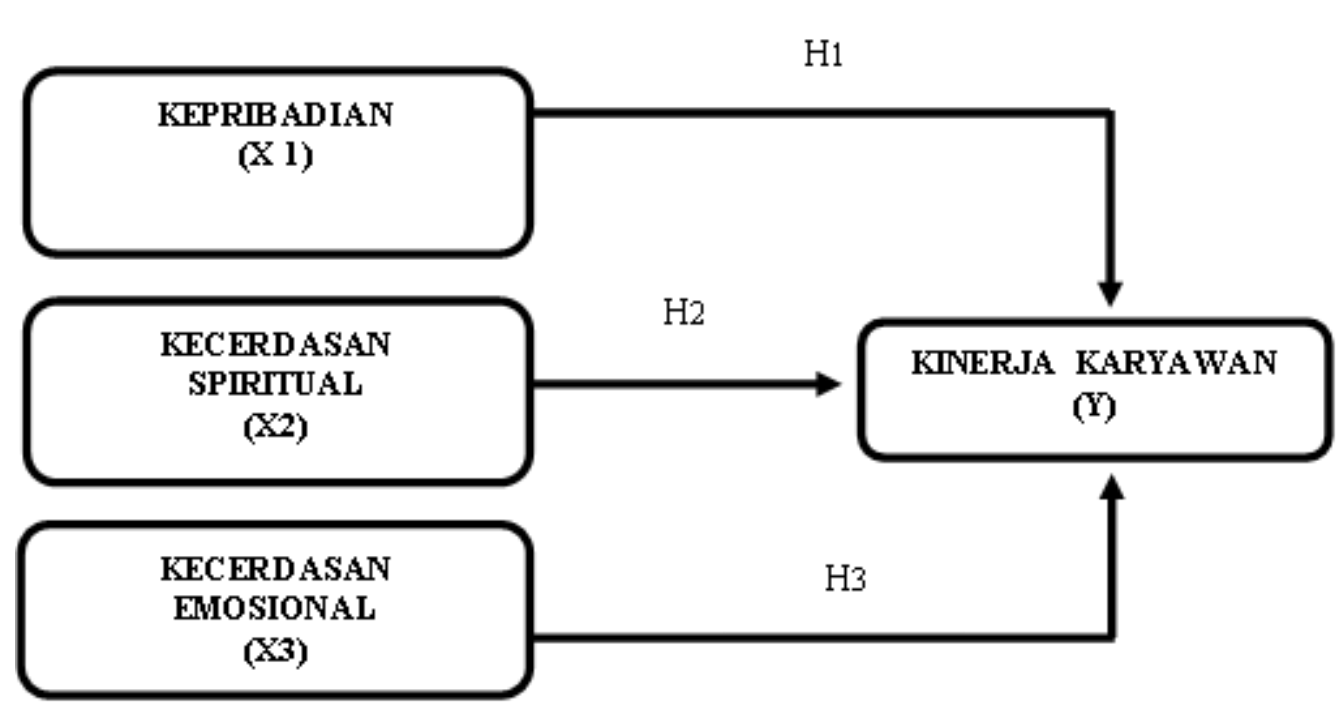

Gambar 1. Kerangka Pemikiran.

\section{Hipotesis}

Berdasarkan landasan teori dan kerangka pemikiran telah diuraikan maka hipotesis penelitiannya dapat diajukan sebagai berikut:

Hasil penelitian Wicaksono dan Surjanti (2016) menemukan bahwa tidak semua trait kepribadian tersebut berpengaruh terhadap kinerja, hanya ada dua indikator yang berpengaruh signifikan terhadap kinerja yaitu Conscientiousness dan Opennes to Experience. Suhandiah et al (2017) menemukan hasil serupa yaitu hanya Conscientiousness dan Opennes to Experience. Gosling et al. (2003) dan Goldberg et al. (2006) dalam Suhandiah et al., (2017) menyatakan Conscientiousness adalah dimensi yang sangat berpengaruh secara konsisten terhadap kinerja karyawan. Selain itu spiritualitas di tempat kerja juga berkontribusi nyata terhadap konstruk perilaku kerja, yaitu menumbuhkan komitmen tinggi terhadap organisasi, memperkecil intensitas keluar dari pekerjaan, memunculkan keterlibatan lebih terhadap pekerjaan serta meningkatkan selfesteem dalam diri (Milliman et al., 2003). Peningkatan spiritualitas di tempat kerja diharapkan akan adanya perbaikan nilai, moral, etika, kreativitas, produktivitas dan sikap kerja (Sufya, 2015).

Hasil penelitian yang dilakukan Shih dan Susanto (2010) menunjukkan bahwa kecerdasan emosional berpengatuh terhadap pada kinerja. Sulaiman dan Noor (2015) menemukan semua dimensi pada WLEIS memiliki hasil yang signifikan. Dalam penelitian Sulaiman dan Noor (2015) dari keempat dimensi hanya dua dimensi yaitu Other's Emotional Appraisal (OEA) dan Use of Emotion (UOE) yang memiliki hubungan siginifikan dan reliabilitas yang tinggi. Penelitian oleh Ramadhani (2016) menunjukkan bahwa hanya dimensi Other's Emotional Appraisal (OEA) memiliki pengaruh sangat signifikan serta memiliki reliabilitas yang tinggi. berikut:

Berdasarkan kajian literatur yang telah dibahas, maka hipotesis penelitian ini sebagai

H1 : Kepribadian berpengaruh positif terhadap kinerja karyawan.

$\mathrm{H} 2$ : Kecerdasan spiritual berpengaruh posisit terhadap kinerja karyawan.

H3 : Kecerdasan emosional other's emotional appraisal (OEA) berpengaruh positif terhadap kinerja karyawan. 


\section{METODE PENELITIAN}

Penelitian ini adalah penelitian kausal yaitu desain penelitian ditujukan untuk membuktikan hubungan sebab-akibat atau hubungan yang mempengaruhi dan dipengaruhi pada variabel-variabel yang diteliti. Variabel yang mempengaruhi aaalah variabel bebas, sedangkan variabel yang dipengaruhi adalah variabel terikat (Sugiyono, 2017: 21). Penelitian ini menggali pengaruh kepribadian, kecerdasan emosional dan kecerdasan spiritual terhadap kinerja karyawan. Penelitian ini dilakukan pada karyawan perusahaan reatil PT. Indomarco Prismatama dan PT. Inti Bharu Mas di Bandar Lampung.

Jenis data yang digunakan penelitian ini adalah data primer dan data sekunder. Data primer diperoleh dari karyawan yang bekerja di PT. Indomarco Prismatama dan PT. Inti Bharu Mas. Karyawan perusahaan-perusahaan tersebut merupakan responden penelitian ini. Instrumen utama penelitian ini adalah kuesioner. Data sekunder merupakan informasi yangdiperoleh dari sumber yang ada seperti melalui website, internet, catatan atau dokumentasi perusahaan dan studi kepustakaan terkait dengan topik penelitian.

\section{Teknik Pengambilan Sampel}

Pengambilan sampel dilakukan dengan menggunakan teknik probability sampling. Teknik probability sampling adalah proportionate stratified random sampling dengan menggunakan rumus slovin. Probability sampling adalah teknik pengambilan sampel yang memberikan peluang yang sama bagi setiap anggota populasi untuk dipilih menjadi anggota sampel (Sugiyono, 2017: 138).

Tabel 1. Jumlah Karyawan

\begin{tabular}{|l|c|c|}
\hline No. & \multicolumn{1}{|c|}{ Perusahaan } & Jumlah Karyawan \\
\hline 1. & PT. Indomarco Prismatama & 314 orang \\
\hline 2. & PT. Inti Bharu Mas & 118 orang \\
\hline \multicolumn{2}{|c|}{ Total Karyawan } & 432 orang \\
\hline
\end{tabular}

Sampel penelitian ini ditentukan dengan menggunakan rumus Slovin sebagai berikut:

$$
\mathrm{n}=\frac{N}{1+N e^{2}}
$$

Keterangan:

$$
\begin{array}{lll}
- & \mathrm{n} & =\text { ukuran sampel } \\
- & \mathrm{N} & =\text { ukuran populasi } \\
- & \mathrm{e} & = \\
& \text { persen kelonggaran ketidaktelitian karena kesalahan } \\
& \text { pengambilan sampel }(5 \%) .
\end{array}
$$

Setelah menggunakan rumus Slovin tersebut selanjutnya ditentukan jumlah sampel dari 432 orang karyawan dengan presisi yang ditetapkan atau tingkat signifikansi sebesar 0,05. Dengan demikian besaran sampel pada penelitian ini adalah : 


$$
\begin{aligned}
\mathrm{n} & =\frac{N}{1+N e^{2}} \\
\mathrm{n} & =\frac{432}{1+432.0,05^{2}} \\
& =207,692 \text { dibulatkan menjadi } 208 .
\end{aligned}
$$

Dengan demikian jumlah keseluruhan responden penelitian adalah 208 orang. Selanjutnya untuk menentukan besarnya sampel pada setiap kelas dilakukan dengan menggunakan proportionate stratified random sampling. Teknik ini ditujukan agar sampel yang diambil lebih proporsional dengan cara. Perhitungan dan jumlah sampel dapat dilihat pada Tabel 2.

$$
\text { Jumlah sampel tiap perusahaan }=\frac{\text { Jumlah Sampel }}{\text { Jumlah Populasi }} X \text { Jumlah karyawan tiap perusahaan }
$$

Tabel 2. Perhitungan Jumlah Sampel

\begin{tabular}{|l|l|c|c|}
\hline No. & \multicolumn{1}{|c|}{ Perusahaan } & Perhitungan & $\begin{array}{c}\text { Jumlah Karyawan } \\
\text { (Sampel) }\end{array}$ \\
\hline 1. & PT. Indomarco Prismatama & $\frac{208}{432} \times 314$ orang & 151 orang \\
\hline 2. & PT. Inti Bharu Mas & $\frac{208}{432} \times 118$ orang & 57 orang \\
\hline \multicolumn{2}{|c|}{ Jumlah } & 208 orang \\
\hline
\end{tabular}

\section{Variabel Penelitian}

Variabel independen yang digunakan di dalam penelitian ini adalah kepribadian $\left(\mathrm{X}_{1}\right)$, kecerdasan emosional $\left(\mathrm{X}_{3}\right)$ dan kecerdasan spiritual $\left(\mathrm{X}_{2}\right)$.Variabel dependen yang digunakan dalam penelitian ini adalah kinerja karyawan (Y).

\section{Metode Pengumpulan Data}

Pengumpulan data dilakukan untuk memperoleh data penelitian yang diharapkan. Pengumpulan darta dilakukan baik berupa data primer ataupun data sekunder. Pengumpulan data dilakukan dengan penyebaran kuesioner berkaitan dengan kepribadian, kecerdasan emosional, kecerdasan spiritual dan kinerja karyawan.

\section{Uji Instrumen Penelitian}

Uji instrumen penelitian adalah uji pendahuluan yang digunakan untuk menguji validitas, reliabilitas dan serta normalitas data. Data yang diperoleh dari tiap item kuesioner yang diisi responden diuji dengan tujuan agar data tersebut dapat digunakan untuk membuktikan hipotesis (Sugiyono, 2017: 203).

1. Uji Validitas, uji ini digunakan untuk mengukur valid tidaknya suatu kuesioner. Teknik pengujian validitas instrumen penelitian dilakukan dengan bantuan software SPSS 18. Selanjutnya data dinyatakan valid apabila rhitung > rtabel (Sugiyono, 2017:251). Apabila korelasi antara skor item dengan skor total lebih besar dari rtabel maka butir dalam instrumen tersebut dinyatakan valid. 
2. Uji Reliabilitas, uji ini dilakukan untuk mengetahui konsistensi alat pengukuran. Uji reliabilitas dilakukan dengan menggunakan program SPSS. Model pengukuran adalah alpha cronbach's. Jika nilai Cronbach's Alpha lebih besar dari 0,60 kuesioner sebagai alat pengukur dinilai reliabel.

3. Uji Normalitas, setiap variabel perlu diuji normalitas datanya. Sugiyono (2017: 234) menyatakan statistik parametris mensyaratkan bahwa setiap variabel yang akan dianalisis harus berdistribusi normal. Oleh karena itu sebelum pengujian hipotesis dilakukan maka terlebih dahulu dilakukan pengujian normalitas data. Suatu data dikatakan berdistribusi normal jika jika Sig > 0,05.

\section{Metode Analisis Data}

Metode analisis kuantitatif dilakukan dengan mengggunakan analisis regresi linier berganda. Analisis regresi ini ditujukan untuk mengukur pengaruh kepribadian, dan kecerdasan emosional dan kecerdasan spiritual terhadap kinerja karyawan pada PT. Indomarco Prismatama dan PT. Inti Bharu Mas. Pengujian hipotesis dilakukan dengan menggunakan uji statistik parsial (uji t). Pengujian ini dimaksudkan untuk mengetahui variabel independen berpengaruh signifikan terhadap variabel dependen secara parsial. Dikatakan terdapat pengaruh signifikan jika sig < $(0,05)$. Hasil uji t dapat dilihat dari output coefficient serta dari uji regresi linier berganda menggunakan SPSS. Kriteria pengambilan keputusan dalam uji $\mathrm{t}$ sebagai berikut: jika thitung > tabel $(0,05)$, maka Ho tidak didukung, Ha didukung. Jika thitung $<$ tabel $(0,05)$, maka Ho didukung, Ha tidak didukung.

\section{HASIL PENELITIAN DAN PEMBAHASAN}

Responden dalam penelitian ini adalah karyawan yang bekerja di PT. Indomarco Prismatama dan PT. Inti Bharu Mas yang berada di Bandar Lampung. Hasil penyebaran kuesioner kepada 208 responden sebanyak 195 kuesioner yang kembali. Berdasarkan data tersebut maka tingkat pengembalian (response rate) sebesar $=(195: 208) \times 100 \%=93 \%$. Kuesioner yang kembali sebanyak 195 kuesioner dan 13 kuesioner tidak dapat digunakan karena responden tidak mengisi kuesioner sehingga tidak dapat digunakan untuk analisis.

\section{A. Karakteristik Responden}

Karakteristik responden berdasarkan usia didominasi oleh karyawan yang berusia 21 - 30 tahun sebanyak 80 orang sebesar $41 \%$. Berdasarkan jenis kelamin didominasi oleh karyawan berjenis kelamin laki-laki sebanyak 127 orang sebesar $65 \%$. Berdasarkan tingkat pendidikan didominasi oleh karyawan dengan tingkat pendidikan S1 sebanyak 86 orang sebesar $44 \%$. Berdasarkan masa kerja didominasi oleh karyawan dengan masa kerja selama $5-6$ tahun sebanyak 67 orang sebesar $34 \%$.

\section{A. Hasil Penelitian \\ Uji Instrumen Penelitian}

\section{Uji Validitas}

Uji validitas yang digunakan dalam penelitian ini menggunakan teknik korelasi pearson product moment dengan bantuan software SPSS versi 18. Pada penelitian ini $r$ tabel $(\mathrm{df}=(\mathrm{n}-2)) /(\mathrm{df}=(195-2=193))$ sebesar 0.1406 dengan tingkat signifikan 0,05. Suatu item pernyataan dapat dikatakan valid jika nilai $r_{\text {hitung }}$ lebih besar daripada $r_{\text {tabel }}\left(r_{\text {hitung }}>r_{\text {tabel }}\right)$. Berdasarkan hasil uji validitas pada Tabel 7 dengan menggunakan 195 orang reponden, dapat dilihat bahwa terdapat beberapa item pernyataan yang dihapus karena tidak valid atau rhitung lebih kecil daripada rtabel (rhitung < rtabel). Item pernyataan yang tidak valid tersebut 
diantaranya adalah item pernyataan X2.7, X2.8, X2.17 dan X2.22 mengenai kecerdasan spiritual (X2).

\section{Uji Reliabilitas}

Uji reliabilitas dalam penelitian menggunakan bantuan program SPSS versi 18 . Pengujian Reliabilitas dilakukan terhadap item-item valid yang yang telah melalui uji validitas pada tahap sebelumnya. Semua item pernyataan kuesioner dapat dinyatakan telah reliabel dengan hasil sebagai berikut:

a. Variabel kepribadian (X1) memiliki nilai cronbach's alpha sebesar 0,656. Nilai ini menunjukkan vairiabel ini memiliki reliabilitas yang tinggi.

b. Variabel kecerdasan emosional (X2memiliki nilai cronbach's alpha sebesar 0,872. Nilai ini menunjukkan variabel memiliki reliabilitas sangat tinggi.

c. Variabel kecerdasan Spiritual (X3) memiliki nilai cronbach's alpha sebesar 0.704. nilai ini menunukkan reliabilitas yang tinggi.

d. Variebl kinerja (Y) memiliki nilai cronbach's alpha sebesar 0,697. Nilai ini menunjukkan reliabilitas yang tinggi.

\section{Uji Normalitas}

Uji normalitas ditujukan untuk mengetahui apakah terdapat variabel pengganggu atau residual didalam model regresi. Residual disebut memiliki distribusi normal jika memiliki nilai signifikansi $\geq 0,05$.

Tabel 3. Hasil Uji Normalitas untuk Variabel Kepribadian, Kecerdasan Emosional, Kecerdasan Spiritual, dan Kinerja Karyawan.

\begin{tabular}{|ll|r|}
\hline & & \multicolumn{2}{|c|}{$\begin{array}{c}\text { Unstandardized } \\
\text { Residual }\end{array}$} \\
\hline $\mathrm{N}$ & Mean & 195 \\
Normal & 0,1348766 \\
Parameters & Std. Deviation & 1,59125172 \\
Most Extreme & Absolute & 0,086 \\
Differences & Positive & 0,086 \\
& Negative & $-0,063$ \\
Kolmogorov-Smirnov Z & 1,202 \\
Asymp. Sig. (2-tailed) & 0,111 \\
\hline
\end{tabular}

a. Distribusi tes normal.

b. Dihitung dari data.

Tabel 3 menunjukkan bahwa nilai signifikansi variabel. Variabel kepribadian, kecerdasan emosional, kecerdasan spiritual dan kinerja karyawan memiliki nilai signifikansi sebesar 0,111 yang artinya > 0,05. Dengan demikian dapat disimpulkan bahwa distribusi data semua variabel telah normal. Hasil statistik deskriptif menjelaskan nilai rata-rata (mean), dan nilai standar deviasi dari semua variabel independen dan variabel dependen. Pada Tabel 3 menunjukkan bahwa dari keempat variabel penelitian yang digunakan secara keseluruhan, jawaban responden variabel terhadap kecerdasan emosional mendapatkan skor mean tertinggi dari variabel lainnya yaitu sebesar 3,9750 dengan standar deviasi sebesar 0,05972. Skor terendah adalah variabel kepribadian dengan nilai mean sebesar 3,8780 dan standar deviasi 0,07315 . 
Tabel 4 Hasil Uji Statistik Deskriptif

\begin{tabular}{|l|l|l|}
\hline \multicolumn{1}{|c|}{ Variabel Penelitian } & \multicolumn{1}{c|}{ Mean } & Std. Deviation \\
\hline Kepribadian & 3,8780 & 0,07315 \\
\hline Kecerdasan Spiritual & 3,9258 & 0,18309 \\
\hline Kecerdasan Emosional & 3,9750 & 0,05972 \\
\hline Kinerja Karyawan & 3,8840 & 0,11415 \\
\hline
\end{tabular}

4. Uji Regresi Linier Berganda

Pada tabel 5 berikut menunjukkan hasil analisis regresi linear berganda menggunakan software SPS.

Tabel 5 Analisis Regresi Linear Berganda

\begin{tabular}{|c|c|c|c|c|}
\hline \multirow[t]{2}{*}{ Model } & \multicolumn{2}{|c|}{$\begin{array}{c}\text { Unstandardized } \\
\text { Coefficients }\end{array}$} & $\begin{array}{c}\text { Standardized } \\
\text { Coefficients }\end{array}$ & \\
\hline & $\mathrm{B}$ & Std. Error & Beta & $\mathrm{t}$ \\
\hline 1 (Constant) & 38,582 & 6,729 & & 5,734 \\
\hline Kepribadian & 0,395 & 0,105 & 0,316 & 3,414 \\
\hline Kecerdasan Spiritual & 0,248 & 0,015 & 0,793 & 16,691 \\
\hline $\begin{array}{l}\text { Kecerdasan } \\
\text { Emosional }\end{array}$ & 0,558 & 0,111 & 0,425 & 2,915 \\
\hline
\end{tabular}

a. Dependent Variable: Kinerja Tugas

Berdasarkan tabel 5 maka hasil perhitungan dengan rumus analisis regresi linier berganda:

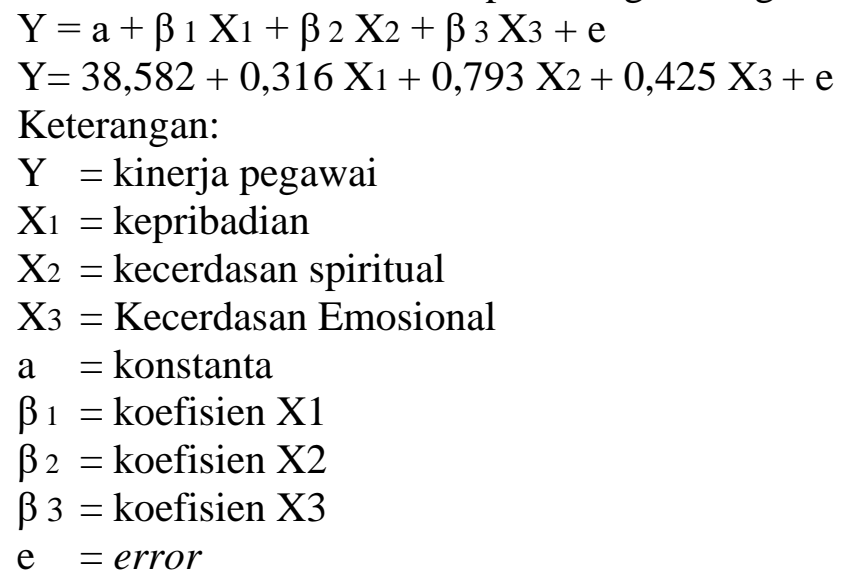

Koefisien regresi variabel X1, X2, X3 bertanda positif $(\beta 1=0,316)(\beta 2=0,793)(\beta 3$ $=0,425)$ artinya terjadi pengaruh positif antara variabel kepribadian, kecerdasan spiritual dan kecerdasan emosional terhadap variabel kinerja karyawan, semakin baik kepribadian, kecerdasan spiritual dan kecerdasan emosional maka semakin baik pula kinerja karyawan.

\section{Uji Hipotesis}

Pengujian hipotesis ditujukan untuk mengetahui pengaruh signifikansi masingmasing variabel bebas terhadap variabel terikat secara parsial. Pengujian ini dilakukan dengan menggunakan uji t pada tingkat kepercayaan 95\% atau dengan nilai $\alpha=5 \%$ serta menggunakan derajat kebebasan df (degree of freedom). 
Keterangan:

$$
d f=n-k-1
$$

$\mathrm{n}=$ jumlah responden

$\mathrm{k}=$ jumlah variabel independen $(\mathrm{X})$

Hasil penghitungan rumus tersebut adalah sebagai berikut:

df $=195-3-1=191$

Diperoleh nilai tabel $(0,05 ; 191)=1,65287$

1. Uji Hipotesis I

Tabel 5 menjelaskan bahwa nilai thitung variabel kepribadian sebesar 3,414 > 1,652 ttabel, sehingga dapat disimpulkan bahwa Ho tidak didukung dan Ha didukung. Variabel kepribadian berpengaruh terhadap kinerja karyawan secara positif signifikan. Semakin tinggi tingkat kepribadian yang dimiliki karyawan maka akan meningkatkan kinerja yang dihasilkan karyawan.

2. Uji Hipotesis II

Tabel 5 juga menjelaskan bahwa nilai thitung variabel kecerdasan spiritual sebesar 16,691 $>$ 1,652 ttabel, sehingga dapat disimpulkan bahwa Ho tidak didukung dan Ha didukung. Variabel kecerdasan spiritual berpengaruh secara positif signifikan terhadap kinerja karyawan. Semakin tinggi kecerdasan spiritual karyawan maka akan meningkatkan kinerja yang dihasilkan karyawan.

3. Uji Hipotesis III

Tabel 22 juga menjelaskan bahwa nilai thitung variabel kecerdasan emosional sebesar 2,915> 1,652 tabel, sehingga dapat disimpulkan bahwa Ho tidak didukung dan Ha didukung. Variabel kecerdasan emosional berpengaruh secara positif signifikan terhadap kinerja karyawan. Semakin tinggi kecerdasan emosional karyawan maka akan meningkatkan kinerja yang dihasilkan karyawan.

\section{B. Pembahasan}

Hasil dari penelitian ini telah menjelaskan uji hipotesis pada setiap variabel dalam penelitian, dengan demikian berdasarkan dari uji hipotesis diatas dapat diambil sebuah pembahasan antara lain:

\section{Pengaruh Kepribadian Terhadap Kinerja Karyawan}

Hasil pengujian hipotesis membuktikan bahwa kepribadian berpengaruh positif secara signifikan terhadap kinerja karyawan. Hal tersebut dibuktikan dengan hasil uji t yaitu nilai thitung sebesar 3,414>1,652 ttabel. Semakin tinggi tingkat kepribadian yang dimiliki karyawan maka akan meningkatkan kinerja yang dihasilkan karyawan. Berdasarkan temuan ini hipotesis yang diajukan didukung yaitu kepribadian berpengaruh positif terhadap kinerja karyawan.

Berdasarkan deskripsi hasil penelitian variabel kepribadian secara keseluruhan, item kepribadian yang memiliki rata-rata paling tinggi adalah item saya mengerjakan tugas secara menyeluruh dengan skor rata-rata 3.97. Berdasarkan deskripsi hasil penelitian variabel kepribadian, dimensi conscientiousness memiliki skor rata-rata tertinggi yaitu sebesar 3.91, sehingga dapat disimpulkan bahwa responden kebanyakan memiliki kepribadian 
conscientiousness dimana mereka senang mengerjakan tugas secara menyeluruh, lebih terorganisir, berhati-hati dan teliti.

Hasil penelitian ini didukung oleh penelitian sebelumnya. Penelitian sebelumnya yang dilakukan oleh Goldberg et al., (2006) (dalam suhandiah et al., 2017) menemukan bahwa conscientiousness merupakan faktor yang secara positif berpengaruh terhadap kinerja. Selain itu Yang dan Hwang (2014) menemukan bahwa semua trait kepribadian secara signifikan berpengaruh positif terhadap kinerja.

\section{Pengaruh Kecerdasan Spiritual Terhadap Kinerja Karyawan}

Hasil pengujian hipotesis membuktikan bahwa kecerdasan spiritual berpengaruh positif signifikan terhadap kinerja karyawan. Hal ini dibuktikan dari hasil uji t yaitu nilai thitung sebesar 16,691 > 1,652 ttabel. Semakin tinggi kecerdasan spiritual karyawan maka akan semakin meningkatkan kinerja yang dihasilkan karyawan. Berdasarkan hasil tersebut maka penelitian ini mendukung hipotesis yaitu kecerdasan spiritual berpengaruh positif terhadap kinerja karyawan.

Berdasarkan deskripsi hasil penelitian variabel kecerdasan spiritual, dimensi conscious state expansion adalah dimensi yang secara keseluruhan memiliki skor rata-rata tertinggi yaitu sebesar 4.02, yang berarti secara keseluruhan responden adalah orang yang berpikir beberapa kali dalam merespons setiap situasi dan mengambil waktu sejenak untuk memahami situasi. Berdasarkan observasi atau pengamatan yang dilakukan saat melakukan penelitian di kedua perusahaan, ketika tiba waktu untuk beribadah, karyawan akan meninggalkan pekerjaan dan berangkat bersama-sama ke masjid yang jaraknya dekat dengan lokasi perusahaan. Selain itu berdasarkan hasil uji t variabel kecerdasan spiritual memiliki skor t hitung tertinggi yaitu sebesar 16, 691, yang berarti kecerdasan spiritual paling banyak berpengaruh terhadap kinerja karyawan.

Menurut Milliman et al., (2003), spiritualitas di tempat kerja berkontribusi nyata terhadap konstruk perilaku kerja individu seperti menumbuhkan komitmen yang tinggi terhadap organisasi, memunculkan keterlibatan yang lebih terhadap pekerjaan, memperkecil intensitas keluarnya individu dari pekerjaan dan meningkatkan selfesteem dalam diri. Menurut Sufya (2015), dengan adanya spiritualitas di tempat kerja dapat menumbuhkan harapan baru terhadap perbaikan moral, etika, nilai, kreativitas, produktivitas dan sikap kerja karyawan.

\section{Pengaruh Kecerdasan Emosional Terhadap Kinerja Karyawan}

Hasil pengujian hipotesis membuktikan bahwa kecerdasan emosional secara signifikan berpengaruh positif terhadap kinerja. Hasil pengujian ini dibuktikan dengan hasil uji t yaitu nilai thitung sebesar 2,915>1,652 ttabel. Semakin tinggi kecerdasan emosional yang karyawan maka kinerja yang dihasilkan karyawan akan meningkat. Berdasarkan temuan ini maka penelitian ini mendukung hipotesis yang diajukan yaitu kecerdasan emosional berpengaruh positif terhadap kinerja karyawan.

Berdasarkan deskripsi hasil penelitian variabel kecerdasan emosional secara keseluruhan dengan dimensi other's emotional appraisal (OEA), item dengan skor rata-rata tertinggi adalah item saya dapat mengamati emosi orang lain dengan baik dengan skor ratarata sebesar 4,05, yang berarti secara keseluruhan responden merasa mampu merasakan dan memahami emosi orang-orang disekitar mereka.

Hasil penelitian seseuai dengan penelitian terdahulu oleh Shih dan Susanto (2010) yang menunjukkan bahwa kecerdasan emosional berpengaruh terhadap kinerja. Selain itu hasil penelitian Sulaiman dan Noor (2015) juga menunjukkan bahwa semua dimensi pada Wong and Law Emotional Intelligence Scales (WLEIS) memiliki hasil yang signifikan. 
Hasil penelitian Indriyani dan Utami (2018) juga menunjukkan bahwa variabel kecerdasan spiritual serta variabel kecerdasan emosional berpengaruh signifikan terhadap kinerja karyawan.

\section{PENUTUP}

Hasil analisis dapat disimpulkan bahwa hipotesis penelitian ini didukung. Kepribadian secara signifikan berpengaruh positif terhadap kinerja karyawan. Hal ini dibuktikan dari hasil uji $\mathrm{t}$ dimana thitung $>$ tabel. Temuan ini mendukung hipotesis yang diajukan yaitu kepribadian berpengaruh positif terhadap kinerja karyawan. Hasil analisis juga menemukan kecerdasan spiritual $\mathrm{n}$ berpengaruh positif secara signifika terhadap kinerja karyawan. Temuan ini dibuktikan dari hasil uji t dimana thitung $>$ tabel. Dengan demikian hasil penelitian ini mendukung hipotesis yang diajukan yaitu kecerdasan spiritual berpengaruh positif terhadap kinerja karyawan. Kecerdasan emosional berpengaruh positif signifikan terhadap kinerja karyawan. Hasil uji t menunjukkan thitung $>$ ttabel, yaitu semakin tinggi kecerdasan emosional karyawan maka akan semakin berpengaruh terhadap kinerja karyawan. Dengan demikian hasul penelitian ini mendukung hipotesis yang diajukan yaitu kecerdasan emosional berpengaruh positif terhadap kinerja karyawan.

\section{Saran}

Saran penelitian ini terkait kepribadian adalah agar meningkatkan kepercayaan diri karyawan. Selain itu menghindari adanya kelalaian karena adanya rasa gugup yang timbul yang dapat berdampak terhadap kinerja. Saran terhadap kecerdasan spiritual karyawan adalah agar senantiasa berfikir dengan baik dalam merespons situasi . selain itu perlu juga mengambil waktu sejenak untuk memahami situasi sehingga dapat mempertahankan kinerja dengan baik. Saran terhadap kecerdasan emosional adalah supaya dapat lebih memperhatikan tenggang rasa sehingga memahami emosi teman kerja dengan lebih baik. Dengan demikian interaksi dalam pekerjaan lebih harmonis dan dapat mempertahankan kinerja yang baik. Saran terhadap kinerja karyawan dalah untuk memperhatikan karyawan agar dapat mengatur rencana kerjanya sendiri dengan baik sehingga dapat memaksimalkan pekerjaannya untuk selesai tepat waktu.

\section{DAFTAR RUJUKAN}

Ashmos, D. P., and Duchon, D. 2000.Spirituality at work: A conceptualization and measure. Journal of Management Inquiry, 9(2), 134-145. Journal of Business \& Economics Research-August, 2009 Volume 7, Number 846.

Friedman, H. S.\& Schustack, M. W. (2016). Kepribadian Teori Klasik dan Riset Modern. Edisi 6. Jakarta: Erlangga.

Goldberg, L. R., Johnson, J. A., Eber, H.W., \& Hogan, R. A. 2006. The International Personality Item Pool and the future of public domain personality measures. Journal of Research in Personality. 40 (1). pp.84-96.

Goleman, Daniel., 2015. Emotional Intelligence. Jakarta: PT. Gramedia Pustaka Utama.

Hasibuan, Malayu S.P. 2014. Manajemen Sumber Daya Manusia. Edisi Revisi, Cetakan ketujuhbelas. Jakarta: PT. Bumi Aksara.

Indarti, Sri., Hendriani, Susi., Mahda, Mutia. 2014. Pengaruh Faktor Kepribadian Pegawai dan Lingkungan Kerja terhadap Kinerja Pegawai Pada Kantor Regional XII BKN Pekanbaru. Jurnal Ekonomi. Vol. 22, No. 1. 
Indriyani, S. D., Utami, N. H. 2018. Pengaruh kecerdasan emosional dan kecerdasan spiritual terhadap kinerja karyawan (studi pada karyawan pt industri kereta api (persero) madiun - jawa timur. Jurnal Administrasi Bisnis. Vol 59, No. 1.

King, D.B. 2008. Rethinking Claims of Spiritual Intelligence: A Definition, Model, and Measure. Tesis. Canada: Trent University.

Koopmans, L., Bernaards, C.M., Hildebrandt, V.H., Vet, H.C.W., de, Beek, A. J. 2014. Construct Validity of Individual Work Performance Questionaire. Journal of Occupational and Environmental Medicine. Volume 56, Number 3. Pp. 331337.

Law, K.S., Wong, Chi-Sum., Song, L.J. 2004. The Construct and Criterion Validity of Emotional Intelligence and Its Potential Utility for Management Studies. Journal of Applied Psychology. Vol. 89, No. 3, 483-496.

Limawandoyo, Alamzah., Eric dan Augustinus Simanjuntak. 2013, Jurnal Manajemen Bisnis: Pengelolaan dan Pengembangan Sumber Daya Manusia pada PT. Aneka Sejahtera Engineering, Universitas Kristen Petra, Vol. 1 No. 2.

Mangkunegara, Anwar Prabu. 2014. Evaluasi Kinerja SDM. Bandung: PT. Refika Aditama.

Milliman, J., Czaplewski, A.J. dan Ferguson, J. (2003). Workplace spirituality and employee work attitudes: an exploratory empirical assessment. Journal of Organizational Change Management, Vol. 16, No. 4, pp. 426-447.

Muhaimin, et al. 2011. Peran Karakteristik Kepribadian, Leader Member Exchange, dan Lingkungan Kerja terhadap Kinerja Karyawan pada PT. Matahari Silverindo Jaya (MSJ) Semarang. Jurnal Bisnis dan Ekonomi (JBE), Pp. 168-184.

Nurtjahjanti, Harlina. 2010. Spiritualitas Kerja Sebagai Ekspresi Keinginan Diri Karyawan untuk Mencari Makna dan Tujuan Hidup dalam Organisasi. Jurnal Psikologi Undip, Vol. 7, No. 1. Fakultas Psikologi Universitas Diponegoro.

Ramadhani, Rahmi. 2016. Uji Validitas Konstruk Terhadap Adaptasi dari Wong and Law Emotional Intelligence Scale (Wleis). Jurnal Psikologi. Vol. V, No. 2.

Rammstedt, B., John, O.P. 2007. Measuring Personality in One Minute or Less: A 10 Item Short Version of The Big Five Inventory in English and German. Journal of Research in Personality, 41, Pp. 203-212.

Robbins, Stephen P., Judge, T.A. 2013. Perilaku Organisasi: Organizational Behavior. Edisi 12. Jakarta: Salemba Empat.

Shih, His-An., Susanto, Ely. 2010. Conflict Management Styles, Emotional Intelligence, and Job Performance in Public Organization. International Journal of Conflict Management. Vol. 21 Iss 2 Pp. 147-168.

Sugiyono. 2017. Metode Penelitian Bisnis. Edisi 3. Bandung: ALFABETA.

Suhandiah., Oktaviani., Ayuningtyas. 2017. Pengaruh Kepribadian terhadap Kinerja Individu: Pendekatan Big-Five Theory. Vol. 5, No. 1.

Sulaiman, W.S.W., Noor, M.Z.M. 2015. Examining The Psychometric Properties of The Wong and Law Emotional Intelligences Scale (WLEIS). Journal of Social Sciences and Humanities. Special Issue 2 081-090, ISSN: 1823-884x.

Wicaksono, T. A., Surjanti, Jun. 2016. Pengaruh Dimensi Kepribadian Terhadap Kinerja Karyawan dengan Pelatihan Sebagai Variabel Mediasi Studi pada PT. Gresik Cipta Sejahtera. Bisnis dan Manajemen Jurnal. Volume 8, No 2.

Yang, Cheng-Liang., Hwang, Mark. 2014. Personality Traits and Simultaneous Reciprocal Influences Between Job Performance and Job Satisfaction. Chinese Management Studies. Vol. 8 Iss 1 Pp. 6-26.

Zohar, Danah., Marshal, Ian. 2013. Memberdayakan SC di Dunia Bisnis. Bandung: PT. Mizan Pustaka. 